\title{
The Language Question in Cameroon
}

\author{
George Echu (Yaounde/Bloomington)
}

\begin{abstract}
In multilingual Cameroon, 247 indigenous languages live side by side with English and French (the two official languages) and Cameroon Pidgin English (the main lingua franca). While the two official languages of colonial heritage dominate public life in the areas of education, administration, politics, mass media, publicity and literature, both the indigenous languages and Cameroon Pidgin English are relegated to the background.

This paper is a critique of language policy in Cameroon revealing that mother tongue education in the early years of primary education remains a distant cry, as the possible introduction of an indigenous language in the school system is not only considered unwanted by educational authorities but equally combated against by parents who believe that the future of their children lies in the mastery of the official languages. This persistent disregard of indigenous languages does not only alienate the Cameroonian child culturally, but further alienates the vast majority of Cameroonians who are illiterate (in English and French) since important State business is carried out in the official languages. As regards the implementation of the policy of official language bilingualism, there is clear imbalance in the use of the two official languages as French continues to be the dominant official language while English is relegated to a second place within the State. The frustration that ensues within the Anglophone community has led in recent years to the birth of Anglophone nationalism, a situation that seems to be widening the rift between the two main components of the society (Anglophones and Francophones), thereby compromising national unity.

The paper is divided into five major parts. After a brief presentation of the country, the author dwells on multilingualism and language policy since the colonial period. The third, fourth and last parts of the paper focus on the critique of language policy in Cameroon with emphasis first on the policy of official language bilingualism and bilingual education, then on the place of indigenous languages, and finally on the national language debate.
\end{abstract}

\section{$1 \quad$ Introduction}

The Republic of Cameroon is a multilingual country comprising some 247 indigenous languages, one lingua franca (Cameroon Pidgin English) and two official languages (English and French). These official languages are the heritage of Franco-British rule in the country between the end of the First World War and Independence. 
This peculiar heterogeneous language situation does not facilitate linguistic communication; on the contrary, it constitutes a major handicap to linguistic communication in view of the absence of a nation-wide lingua franca that serves as a common linguistic idiom. Moreover, the unequal distribution in the usage of English and French as official languages is also a cause for concern since it affects negatively the policy of official language bilingualism. In short, language policy in the country lacks clear-cut objectives and orientation: it does in no way sufficiently promote the indigenous languages and fails to guarantee the appropriate implementation of official language bilingualism. Hence the policy of official language bilingualism, originally aimed at guaranteeing political integration and unity of the Cameroon State, now seems to constitute a source of conflict and political disintegration.

The language question in Cameroon can be traced as far back as the colonial period, a period characterized by language conflict between the colonial administrations on the one hand and missionaries on the other. For Cameroon today, the issue at stake is basically that of grappling with its highly multilingual situation, resolving the national language issue, while effectively coping with the official language bilingualism option as well as its implications.

\section{Cameroon in a Nutshell}

According to the CIA World Fact Book, the population of Cameroon is estimated at $15,803,220$ inhabitants as of July 2001. With a surface area of $475,442 \mathrm{~km}^{2}$, it is bounded to the west by Nigeria, to the northeast by Chad, to the east by Central African Republic and to the south by Equatorial Guinea, Gabon and Congo. There are ten administrative regions, two (2) of which are English-speaking and eight (8) French-speaking. ${ }^{1}$

Historically, Cameroon was founded around 1472 by a Portuguese navigator called Fernando Po who arrived the Bight of Biafra, then sailed up the Wouri River situated in the Coastal region. The navigator was surprised to see shrimps in the river, and so baptized the river "Rio dos Camarões" (river of shrimps). This name which was to be associated to the country became "Kamerun" during the German colonial period and "Cameroon" or "Cameroun" during British and French colonial rule. In 1884, Germany colonized Cameroon. The signing of the Germano-Douala treaty in July 1884, whereby Cameroon became a German protectorate, marked this event. But with the defeat of Germany in 1916 during the First World War, Cameroon was divided between Britain and France, and administered first under the League of Nations mandate and later under the United Nations trusteeship. Britain got two discontinuous strips of land of about $90,000 \mathrm{~km}^{2}$ along the Nigerian border: the strip to the north was called "Northern British Cameroons" and that to the south was called "Southern British Cameroons". The French got the lion's share and administered it as an independent territory, whereas the British administered theirs from Lagos in Nigeria.

French Cameroon became independent on 1 January 1960. Then on 11 February 1960, British Southern Cameroons voted union with French Cameroon through a referendum. This

\footnotetext{
1 The English-speaking provinces are North-West and South-West, while the French-speaking provinces are Adamawa, North, Far North, West, Centre, Littoral, South and East.
} 
association between the two entities was consolidated on 1 October 1961 through the Reunification of Cameroon and creation of a federation made up of two states called West Cameroon and East Cameroon. ${ }^{2}$ The federation survived till 20 May 1972 when a unitary State made up of seven (7) provinces was created. And later in 1984, the number of provinces was increased to ten (10) through a Presidential decree.

In the area of education, two subsystems exist in Cameroon: the Anglophone system of education based on the Anglo-Saxon model and the Francophone system based on the French model. Although the two are used side by side, a bilingual system of education is also operational at the university level where studies are carried out in both English and French. According to 1995 estimates, the literacy rate is evaluated at $63.4 \%$ of the total population, $75 \%$ for male and $52.01 \%$ for female (Encyclopedia Britannica, 1995).

\section{$3 \quad$ Multilingualism and Language Policy}

\subsection{Multilingual Cameroon}

As stated earlier, Cameroon is a multilingual country comprising 247 indigenous languages, two official languages and Cameroon Pidgin English (see Breton and Fohtung, 1991; Boum Ndongo-Semengue and Sadembouo, 1999). Although Ethnologue (2002) puts the number of indigenous languages for Cameroon at 279, these figures are challenged by linguists such as Wolf (2001) for not being an accurate reflection of the current language situation, more so since dialects of the same language are sometimes considered as different languages. ${ }^{3}$ Among the indigenous languages, four are on the verge of extinction; they are Duli, Gey, Nagumi and Yeni, all from the northern part of the country (Boum Ndongo-Semengue and Sadembouo, 1999). Ethnologue (1996) relates that 14 others are extinct. Among the four major language families of Africa, three are represented in Cameroon. They are the Afro-Asiatic, the NiloSaharan and the Niger Kordofanian. The Niger-Kordofanian family is the most highly represented in Cameroon, while the Khoisan family is not represented at all.

The languages of wider communication are Fulfulde, Ewondo, Basaa, Duala, Hausa, Wandala, Kanuri, Arab Choa, Cameroon Pidgin English (Breton and Fohtung, 1991: 20) and French. In all, three lingua franca zones can be distinguished in Cameroon: the Fulfulde lingua franca zone in the north, the Pidgin English lingua franca zone in the west and the French lingua franca zone in the rest of the country (Wolf, 2001: 155). Such division should not be considered to be rigid, given the overlapping observable in terms of language use.

The Fulfulde lingua franca zone, which covers the Adamawa, the North and the Far North provinces, constitutes $162,107 \mathrm{~km} 2$ or $34.8 \%$ of the total area of Cameroon. In terms of

\footnotetext{
${ }^{2}$ While West Cameroon was English-speaking, East Cameroon was French-speaking.

${ }^{3}$ When one observes the classification made by Ethnologue (2002), the following pairs are classified as distinct languages: Fali North and Fali South; Fulfulde Adamawa and Fulfulde Kano; Gbaya Northwest and Gbaya Southwest; Giziga North and Giziga South; Mofu North and Mofu South. One really wonders if the distinction made from the geographical point of view does not point to the fact that these pairs are dialects of the same language.
} 
demographic strength, Fulfulde is spoken by close to 3 million people as a second language, although native speakers of the language are evaluated at more than 350,000speakers. As far back as the $17^{\text {th }}$ century it served as the language of Islam in the north of the country.

Cameroon Pidgin English (CPE) is widely used not only in the North-West and South-West provinces, but also in the Littoral and West provinces. Presently, its influence is felt in several major towns of the Francophone provinces. In short, CPE is no longer perceived exclusively as a lingua franca of the English-speaking population, but a language that has a possible national dimension. In urban as well as rural areas, CPE is used in churches, in market places, in motor parks, in railway stations, in the street, as well as in other informal situations. In fact this 'no man's language' is very present in the daily socio-economic lives of the people, a role it began to play as far back as the German colonial period.

As for French, its role as a language of wider communication is traced to the postindependence period, following the gradual but massive acquisition of this language by Cameroonians. Thus apart from the three northern provinces (where Fulfulde thrives as a lingua franca) and the two English-speaking provinces (where Pidgin English is the de facto lingua franca), French plays this role in the rest of the other five Francophone provinces. In this regard, a variety of popular French has come to be used in informal contexts among heterogeneous ethnic groups, especially in urban and semi-urban areas. In all, French as a language of wider communication is used nationwide between Anglophones and Francophones, Fulfuldophones and Francophones (who do not understand Fulfulde), and among Francophones who do not share a common language.

The two official languages, English and French, came into the Cameroon scene in 1916 when Britain and France shared Cameroon into two unequal parts after defeating the German forces in the country. The new colonial masters then sought to impose their languages in the newly acquired territory both in the areas of education and administration. This led to the solid implantation of the two languages during the colonial era, a situation that was later reinforced after Cameroon became independent. At Reunification in 1961, English and French became the two official languages of Cameroon as the country opted for the policy of official language bilingualism.

\subsection{Language Policy during the Colonial Era}

It is important to note that during the pre-colonial period some indigenous languages had already gained a considerable degree of prestige. This is true of the Bamun language that was standardized by Sultan Njoya and used for teaching long before the arrival of the German missionaries, and also Fulfulde, which had been used for the dissemination of Islam in the three Northern provinces as far back as the $17^{\text {th }}$ century.

During the colonial period, the colonial powers encouraged the use of their respective languages. Although the German colonial administration (1884-1916) encouraged the use of German, German Missionaries and the American Presbyterian Missionaries preferred indigenous languages like Basaa, Bulu, Duala, Ewondo and Mungaka for teaching and evangelisation (Mbuagbaw, 2000: 135). In spite of the undeveloped nature of the German 
public school system in Cameroon, the colonialists nonetheless tried to impose the use of German in schools ${ }^{4}$ by exerting pressure on the missionaries. Thus the missionaries continued to be in control of the language situation, since they had a serious stronghold on the school system.

In all, throughout the German colonial period, indigenous languages continued to enjoy a somewhat comfortable position as far as linguistic communication is concerned.

Following the defeat of Germany in Cameroon, language policy witnessed some changes with the arrival of new colonial powers. The British practised the policy of Indirect Rule whereby the use of indigenous languages was almost an imperative since British administrators governed through traditional authorities. In French-speaking Cameroon, the policy of Assimilation aimed at transforming Cameroonians into Frenchmen gave little or no room for the use of indigenous languages. In the territory under British mandate, some indigenous languages like Bafut, Duala, Kenyang and Mungaka were used alongside with English in schools (Bitja'a Kody, 1999: 82). In short, while the British allowed education in their colonies to be the responsibility of private and religious organizations, the French colonial administration assumed exclusive responsibility for the education of its African subjects (Bokamba, 1991: 183).

Generally, the language situation in French-speaking Cameroon during the colonial period was characterised by perpetual language conflict between missionaries who persisted in the use of indigenous languages and the French colonial administration (cf. Stumpf, 1979; Bitja'a Kody, 1999). The latter took a series of measures aimed at promoting French, while at the same time relegating indigenous languages to the background. In 1917, the French colonial administration instituted a special subvention for schools that used French as the language of instruction. Eventually, schools that taught in indigenous languages were closed down. This is expressed in decisions rendered public on 1 October 1920 and 28 December 1920 whereby the 47 schools opened by King Njoya in the Bamun region (where Bamun was the language of education) were all closed down. As from 1922, 1,800 schools run by the American Presbyterian missionaries, and in which Bulu was taught suffered the same fate. This systematic linguistic persecution (cf. Stumpf, 1979) was carried out with vigour, until French became the sole language in use for education. This notwithstanding, indigenous languages continued to serve not only for evangelisation but also for popular communication. In other words, while the official language remained the monopoly of official communication, the indigenous languages dominated unofficial communication in churches, the market place, cultural celebrations, ritual ceremonies, the home, etc. Thus language policies put in place by the Germans, the British and the French did in no way favour the emergence of an indigenous language that could easily serve as a national language at independence.

\footnotetext{
4 The first public school opened by the Germans was in 1907. In all, prior to World War I, the German administration owned altogether four elementary primary schools, two advanced primary schools and three agricultural schools. On the contrary, the missionaries had more than a hundred schools.
} 


\subsection{Language Policy in Post-colonial Cameroon}

When Cameroon finally became independent, French was adopted as the official language in French-speaking Cameroon while English assumed the same status in the English-speaking sector. Then following reunification on 1 October 1961, official bilingualism was instituted in the new federal republic. Cameroon, like many other African countries, naturally opted for the 'neutral' foreign language option as official language in order to avoid language conflict on the one hand and unwarranted financial and material cost on the other. This explains why the indigenous languages were kept far away and preference given to the languages of the former colonial masters. Intellectuals like Fonlon (1963) did not hesitate to advocate early bilingualism for the Cameroonian school child, a situation whereby English and French will be introduced in the early years of primary education when it is believed children are psychologically and physiologically more apt to learn new languages.

As for the indigenous languages, they virtually had no place in the early years of the postindependence era. Notwithstanding the silence on the part of the government, different organs have been working relentlessly towards the promotion of indigenous languages. This is the case of PROPELCA (Programme de Recherche Opérationnelle pour l'Enseignement des Langues au Cameroun), which has been active since 1977 as regards mother tongue education in Cameroon. Other actors include SIL-Cameroon, the Cameroon Association for Bible Translation and Literacy (CABTAL) and the National Association of Cameroonian Language Committees (NACALCO). Equally significant is the harmonisation of the writing system of Cameroonian languages in 1979, a factor that has contributed immensely to the standardisation of some indigenous languages. Consequently, the revised Constitution of 18 January 1996 which guarantees the pursuit of the policy of official bilingualism and the promotion of national languages only goes a long way to confirm the fact that both the official and indigenous languages are important components of the Cameroonian cultural heritage. Another important development is that in 1998, the parliament passed a bill on the general orientation of education in Cameroon with special emphasis on the teaching of national languages, a bill that was subsequently promulgated into law No 98/004 of 14 April 1998 by the Head of State (Mba and Chiatoh, 2000: 5). Although the Ministry of National Education is yet to outline the practical modalities for the application of this law, there is no doubt that the stage is set for eventual action. However, one doubts the feasibility in the implementation of this law; and whether the law will not simply be like others (e.g. the 1996 Constitution) that are still awaiting implementation. No wonder this law raises some scepticism among critics who believe that although it constitutes a bold attempt and serious commitment on the part of the State, the very fact that implementation is taking too long gives the impression that this initiative, like the 1996 Constitution, was either precipitated or not well thought out. In all, one serious issue continues to loom the mind: whether it suffices to teach the indigenous languages as subjects (which is what the text implies) or actually use them as a medium of instruction, thereby promoting mother tongue education. Nevertheless, in keeping with the spirit of the text, other problems such as the educational cycle(s) concerned with the teaching of indigenous languages, the particular classes involved with such teaching, the number of hours reserved for it, the criteria for the recruitment, training and promotion of indigenous 
language teachers, the structures in charge of the implementation of this policy, as well as financial sources to be used for the implementation need to be addressed in a careful and well thought out manner.

Globally speaking, the linguistic scenario in Cameroon like in most Sub-Saharan African countries is characterized by dense multilingualism; the official dominance of ex-colonial languages; the official neglect of indigenous languages; the unsevered colonial umbilical cord; and socio-politically interwoven language-related problems (Adegbija, 2000: 80f).

\section{$4 \quad$ Official Language Bilingualism and Bilingual Education}

As earlier observed, the policy of official language bilingualism constitutes the main core of Cameroon's language policy. Article 1, paragraph 3 of the Constitution of 18 January 1996 is abundantly clear in this regard:

The official languages of the Republic of Cameroon shall be English and French, both languages having the same status. The State shall guarantee the promotion of bilingualism throughout the country. It shall endeavour to protect and promote national languages.

Although successive Constitutions of the country since independence have always reiterated the policy of official bilingualism, there exists no well-defined language policy till date as to its implementation. In the first place, in spite of the fact that English and French are considered to be equal in status as per the new Constitution, French has a de facto dominance over English in the areas of administration, education and the media. In fact, it is not an exaggeration to say that French influence as expressed in language, culture and political policy prevails in all domains (Wolf 1997: 421). The domination of French is due to the demographic factor, the fact that Francophones have continued to occupy top ranking positions in government and the civil service, and also because there is no effective language policy that guarantees the rights of minorities.

Furthermore, the policy of official language bilingualism has created an Anglophone/Francophone divide in Cameroon that is seen in recent years to constitute a serious problem for the State. Thus, while being a unifying force, official language bilingualism also constitutes a factor of disunity or conflict. This situation has created a sense of cultural identity among Anglophones, which arises from their using the same language (English becoming a symbol of in-group solidarity) in an environment perceived as hostile to them both linguistically and socio-politically (Wolf, 1997). The Anglophones have remained very jealous about maintaining their geographical territory within the Cameroon state. Thus rumours that arose in the 90s over the possible idea of creating regions that will witness the annexation of the Anglophone provinces into Francophone neighbouring provinces (SouthWest and Littoral; North-West and West) so as to form autonomous regions, were out-rightly rejected and combated against. This was perceived by Anglophones as a design on the part of the government to annex the Anglophone provinces and eventually eradicate the Anglophone culture. And so caught between the various alternatives that characterized the political landscape at the time the new Constitution was being prepared in a process referred to as 
'grand débat', 5 Anglophones generally preferred the mid way compromise of the country being partitioned into ten autonomous regions. ${ }^{6}$

In order to promote the policy of official language bilingualism, bilingual education has been implemented in Cameroon since 1961. This entails the use of the two official languages in education, especially at the university level. In four of the six state universities, English and French are used as languages of instruction in lecture halls wherein Anglophones and Francophones sit side by side in the same classroom. Thus the professor employs the official language he masters better for his lecture. On their part, students take down notes and do tests and assignments in the language of their choice. However, the practice of bilingual education in the Cameroon university system is plagued by a number of problems. The first is that most of the lectures are delivered in French in view of the numerical advantage of Francophone professors, a situation that is deplored by the Anglophone minority who feel that they are cheated. Studies carried out by Tambi (1973) and Njeck (1992) are unanimous on the fact that at the University of Yaounde $80 \%$ of lectures are delivered in French and only $20 \%$ in English. This state of affairs contributes to the disgruntled attitude of Anglophones vis-à-vis the policy of official language bilingualism. The second problem brought about by bilingual education is that the system of evaluation is deemed unreliable. It is not uncommon for students to blame failure in examinations to the fact that the professor concerned lacks the linguistic competence to properly understand students' examination scripts in his second official language (LO2). This only goes a long way to create a situation of frustration and mutual suspicion between Anglophones and Francophones. The third problem is that created by Bilingual Training classes designed to enable a better mastery of the students' LO2 (French for Anglophones and English for Francophones). ${ }^{7}$ These classes are not only poorly organised but equally lack the necessary infrastructure, facilities, and motivation on the part of the students to be really successful (Biloa, 1999). The result is the encouragement of a system that does not promote excellence. While there is need to improve on the system of bilingual education as practised in the Cameroon University in the area of teaching methodology, it is necessary for professors to be equally proficient in the two official languages. This will reduce suspicion of unfairness from the students at the level of evaluation, and the feeling from the Anglophone minority that they are marginalized.

\footnotetext{
5 On the eve of political debate initiated by the Head of State to submit proposals for the new Constitution, ideas were solicited from different components of the society (Government, political parties and the civil society). President Biya himself referred to this forum as the 'grand débat'.

6 The various alternatives that characterized the political landscape were: a) secession of the two Anglophone provinces from the Republic of Cameroon; b) return to the federal structure of 1961 ; c) creation of ten autonomous regions; and d) creation of four regions in which the two Anglophone provinces were to be part of two different regions. These regions were to be constituted as follows: the three northern provinces were to make up one region, the second region was to be made up of the Center, South and East provinces, the third region was to be made up of the Littoral and South-West provinces, and the fourth region was to be made up of the NorthWest and West provinces.

7 Bilingual Training is the name given to a special language-training program instituted in the Cameroon university system in 1962. It entails the teaching of French to Anglophone students and English to Francophone students at the university so as to enable them follow up courses in the two official languages without problems.
} 
It is also important to note that the presence of two official languages in Cameroon has imposed two distinct educational subsystems, a situation that poses problems that call for specific responses. In the Francophone subsystem, English is a compulsory subject up to the end of secondary education. This is not the case with French in the Anglophone subsystem, where it is compulsory up to the GCE Ordinary Level. This means that the Francophone student is generally more prepared to affront bilingual education at the university than his Anglophone counterpart. In addition, the two subsystems practise two different methods of evaluation, an equally disturbing situation for educational experts. While in the Anglophone subsystem the student specialises early by choosing a certain number of subjects in which he will seat for the GCE Ordinary Level examination, in the Francophone subsystem all subjects are compulsory and success is based on scoring at least the average mark. In addition, as far as the teaching of foreign languages is concerned, the Francophone secondary school clearly offers more opportunities than the Anglophone school. In Francophone secondary schools, Spanish and German are taught as subjects throughout the secondary school cycle whereas in Anglophone secondary schools they are not. Consequently, Francophones have an edge over Anglophones in the mastery of foreign languages, Spanish and German being the main foreign languages taught in Cameroon. Such a situation may be another source of frustration for the Anglophone minority.

In all, the implementation of the policy of official language bilingualism betrays total absence of language planning. Very little is done in the domain of corpus planning and almost nothing is done in the area of language policy evaluation. In spite of the awareness that both English and French are fast growing to cope with the realities of a multilingual landscape, no serious attempts are made to develop these languages. Work on lexical standardization of Cameroon English and Cameroon French is seriously lagging behind due to lack of institutional support. Such support is obviously necessary for the promotion of the two official languages.

\section{The Place of Indigenous Languages}

In a country where official usage is reserved solely for official languages, indigenous languages continue to be limited largely to oral usage, as well as in rural and family circles. As Bitja'a Kody (2001) aptly remarks:

Les langues nationales sont réduites à un usage oral, grégaire et familial. Leur fonction emblématique n'est exploitée qu'à des fins politiques ponctuelles lors des campagnes électorales. Aucune de ces langues n'est utilisée ni dans l'administration, ni dans la presse écrite, ni dans la publicité, ni à la télévision nationale, ni dans l'enseignement formel, ni dans les campagnes d'alphabétisation financées par le budget de l'Etat. (Indigenous languages are reduced to usage in oral, rural and family contexts. Their emblematic function is exploited only for sporadic political ends during electoral campaigns. These languages are neither used in the Administration, the written media, publicity, national television, formal education, nor in sensitisation campaigns financed by the State budget.)

Their very existence is threatened today, especially in towns and cities where more and more young people tend to use the official languages from childhood. According to Bitja'a Kody (2001), findings from an earlier study carried out on language use in the city of Yaounde 
reveal that $32 \%$ of young people between 10 and 17 years old in Yaounde do not speak any Cameroonian indigenous language. French is their only language of communication. The author affirms that this population is bound to increase in an exponential manner by the next generation, given that such Cameroonians will not be in a position to transmit the indigenous languages to their children. This situation is suicidal for the indigenous languages, which are bound to continue dying progressively.

That the present Constitution underscores the promotion of indigenous languages whereas previous Constitutions (1961, 1972 and 1984) were simply silent on the matter is rather significant. Moreover, the State encourages private initiative in this domain. This explains why experimental projects in the area of teaching and research have long been carried out through private initiative with the silent approval of the government. Such initiatives as observed through the action of SIL-Cameroon, CABTAL, NACALCO, etc. constitute the way forward in the right direction, since national languages are promoted through standardisation, teaching and research, as well as their effective use at the socio-cultural level. Unfortunately, indigenous languages continue to be completely absent from the school curriculum in spite of the fact that "the early use of the mother tongue in education has significant long term benefits with respect to maximising the development of the intellectual potential of the child" (Chumbow, 1996: 5).

Unfortunately, Cameroon, unlike some other Sub-Saharan African countries where the indigenous languages are used as the medium of education in the first three years of primary education, still uses exclusively the two official foreign languages at all levels of education. In view of this situation, attitudes towards the official languages are positive, whereas they are negative towards the indigenous languages. These negative attitudes observed towards the indigenous languages are not peculiar to Cameroon alone, for as Adegbija (2000: 84) notes:

In fact, in schools in many former French and Portuguese colonies, indigenous languages are not tolerated at all even at primary school level, partly because the present level of language development efforts makes this impossible and also partially because of the clamour of parents for their children to be introduced to European languages as early as possible.

Experience has shown that most parents in Cameroon seem to be generally hostile towards the introduction of early childhood education in the indigenous languages. ${ }^{8}$ Several parents send their children to nursery schools as early as the age of three, where the language of communication is English or French. It is obvious that parents who expose their children at an early age to the official language will be totally against the introduction of indigenous languages in the early years of primary education. Such unfavourable attitudes do not augur well for the introduction of indigenous languages in the school system. The nursery schools, it

\footnotetext{
8 This phenomenon is neither new nor strange. Pierre Alexandre (1963: 54) reports that during the colonial period when some French nationals advocated in the French parliament that African languages be used in Africa for education, African representatives in parliament were those who vigorously challenged the motion on the grounds that it would create two unequal systems of education - one for Africans and the other for French. In such a situation, they argued, the educational gap between the two would be widened in favor of those that have acquired French education.
} 
should be noted, very often follow the British, American or French models of education in terms of pedagogic and cultural material used. This attitude ties up with the view that West African countries formerly colonised by the French are still largely linguistically and culturally dependent, a dependency attitude that has dangerously impeded the growth of their indigenous languages (Adegbija, 2000: 84).

It is however important not to undermine the risk of advocating a multilingual education policy in Cameroon at the present time when the educational budget is very tight, and often does not permit the Cameroonian child to have the barest minimum in terms of didactic material, well adapted teaching methodology, school equipment, teachers, etc. Until recently, the government was unable to employ primary school teachers for over a period of ten years. The outcome is that many classrooms lack teachers, and so most of the children receive little or no education at all. If the economy cannot sustain a school system that operates in one of the two official languages, could it possibly sustain the introduction of an indigenous language in the junior classes of primary education? The introduction of mother tongue education in Cameroon, while being practically feasible, may not be economically realistic for a country in which many of its primary school teachers are presently paid through World Bank funding.

By using exclusively English and French in education as well as in official day-to-day interaction and functions in Cameroon, many of the indigenous people remain largely ignorant and unable to participate in crucial national issues, and thus contribute in national development. Many of them neither know the content of the constitution nor the penal code of their country, basic legal documents that guide their lives. This means that the functioning of the State remains a largely elitist affair, since no adult education program is yet to be operational. ${ }^{9}$ It goes without saying that a trilingual language policy model such as that advocated by Tadadjeu (1975), whereby English, French and indigenous languages are encouraged not only in education but also in other domains, will reap considerable benefits for Cameroonians. In our opinion, the following major indigenous languages could be incorporated into the school system and used in primary education: Basaa, Bulu, Ewondo, Duala, Fe'fe', Fulfulde, Mungaka and Cameroon Pidgin English. Basaa will be used by Basaaphones in the Littoral and Centre provinces; Bulu and Ewondo will be used in the Centre, South and East provinces; Duala will be used by Dualaphones and some ethnic groups that belong to the Sawa group like the Bakweri and the Bakossi in the South-West province, as well as the Mbo in the Littoral province; Fe'fe' will be used in the West province; Fulfulde will be used in the three northern provinces; Mungaka will be used in the North-West province; and finally, CPE will be used in the South-West and North-West provinces by pidginophones.

\footnotetext{
9 The fact that a great number of Cameroonians live in complete ignorance as to the functioning of the State is no cause for concern to the authorities in place who enjoy such a situation, given that the possibilities of criticizing government action are reduced to a minimum.
} 


\section{The National Language Debate}

Since independence, the choice of a national language (s) has been problematic. Although government seem to have dismissed the issue altogether, for fear of language conflict likely to threaten national unity, some leading intellectuals, educationalists and linguists have been more than ever preoccupied with the national language problem. Ngijol (1964) advocates the adoption of a single national language in Cameroon for communication, education, literacy and the promotion of national cultural identity. Bot Ba Njock (1966) is in favour of a scenario whereby the country will be divided into linguistic zones, with one language chosen for each zone. Though practical, this proposal could meet with serious difficulties in some areas where the problem of a dominant language is difficult to resolve. This proposal probably encouraged the promotion of six zonal languages in the sixties by teaching them in the Federal University, an initiative that was later suppressed for fear that those Cameroonians whose languages were not chosen will revolt (Chumbow, 1996: 7-8). And in order to put an end to issues of precedence in terms of which language (s) is more important than the other (s) and thus give the impression that they are equal in status, it was unanimously recommended that the term 'national language' should be used henceforth to refer to all Cameroonian vernacular languages. This decision was taken during the inaugural meeting of the National Council for Cultural Affairs in Yaounde from 18 to 22 December 1974.

The government thus betrayed lack of boldness at a time when courage was needed to take a bold step in the right direction. Such failure has made it necessary for initiative to come from other quarters. This is the case of the ten provincial radio stations where emphasis has been made on the promotion of languages widely spoken in each province. The time allocated for radio broadcast in indigenous languages varies from one province to the other. Whereas the Far North provincial radio station in Maroua comes first with $27.36 \%$ of broadcast time given to indigenous languages, the North-West provincial station in Bamenda comes last with barely $4.17 \%$ of broadcast time for indigenous languages (cf. Nga Minkala, 1993 for more details). Such disparity in the time allotted to national languages points to the fact that each provincial radio station determines its own language policy in the area of radio broadcast. On the whole audio-visual communication takes place predominantly in English and French, a situation that further reveals that an important component of the population that constitutes the socio-economic force of the nation is marginalized.

Like Ngijol (1964), Todd (1983) also believes in the idea of choosing a single national language for Cameroon. In her opinion, CPE can effectively play the role of national language not just because it is structurally close to the vernaculars but also because it is the only language in Cameroon which is not associated with a particular tribe, region or religion, or with a specific colonial government (Todd, 1983: 169). Thus its neutrality is seen as a strong unifying factor, since it is clearly a 'no man's language'. This argument is however contested by those who hold that given the long association of Pidgin English to the English language and the fact that its lexicon is made up of a high proportion of words of English origin, its 
neutrality is questionable. ${ }^{10}$ Nevertheless, given that it is a widely spoken language in Cameroon and cuts across linguistic boundaries, it can be conveniently used for education, Todd (1983: 169) argues:

There would be a few linguistic or financial problems in the adoption of Cameroon Pidgin English as a language of education. It is widely understood, a shared lingua franca with Cameroon's African neighbours and, while rarely the only mother tongue of a child, is often one of the first languages he hears. It has long been used as a vehicle for Cameroon culture and has been found perfectly capable of expressing Christian teachings, parliamentary proceedings and financial negotiations.

Since CPE is perceived as a Cameroon language, it can conveniently play this role without much difficulty. Furthermore, the cost of standardization will be minimal, given that some written material already exists in the language. In spite of such advantages, political authorities in present day Cameroon are very reticent to encourage the use of CPE.

\section{$7 \quad$ Conclusion}

Although the Cameroon political system since independence has been relatively stable to permit the implementation of a constructive language policy, this seems not to have been a major preoccupation of the government. The reason for this may be attributed principally to the fact that in Cameroon like in many other Sub-Saharan African countries, language questions are viewed as secondary or less important to be taken rather seriously. So long as the system appears to be working, so long as there is no major crisis, no one cares. In spite of the rambling of linguists and other interested scholars, Cameroonian political authorities seem to be satisfied with the status quo. Thus language policy is, to say the least, a reflection of the State where issues relating to policy and planning are not handled with any long-term perspectives.

Thus a balanced language policy will become effective when mother tongue education is introduced in the early years of primary education, the official languages being introduced later on. Such a policy will only be realistically implemented gradually where possible, especially in the rural areas. The indigenous language(s) of a particular region will thus be used in teaching and promoted at different levels. And, where applicable, one or more indigenous languages could be promoted at the sub-divisional, divisional or provincial levels. Once more, through government endeavour, local councils, language committees and individual initiative, the teaching of English and French on the one hand and indigenous languages on the other should be encouraged nation-wide.

The question of language therefore continues to be preoccupying in the Cameroonian context where the present language policy maintains an important component of the population in total ignorance, since these "illiterate" people lack the basic competence in the languages of the State. Besides, in the absence of mother tongue education, learning at the early stages of elementary school remains perilous to many, leading to a high failure rate in school. And to

\footnotetext{
10 According to this view, CPE is closer to the Anglophone than to the Francophone community both
} linguistically and culturally. 
crown all, the apparent lack of vision in the implementation of the policy of official language bilingualism is fast degenerating into a potential conflict situation between Anglophones and Francophones. In this regard, language issues in Cameroon need to be more seriously addressed than has been the case in the past and even today.

\section{References}

Adegbija, Efurosibina (2000): "Language Attitudes in West Africa". International Journal of the Sociology of Language 141: 75-100.

Alexandre, Pierre (1963): "Aperçu sommaire sur le pidgin A 70 au Cameroun". Cahiers d'Etudes Africaines Vol. III, No. 2: 577-582.

Biloa, Edmond (1999): "Bilingual Education in the University of Yaounde I: The Teaching of French to English-Speaking Students". In: Echu, George/Grundstrom, Allan W. (eds.): Bilinguisme officiel et communication linguistique au Cameroun. New York: 53-74.

Bitja'a Kody, Zachée Denis (1999): "Problématique de la cohabitation des Langues". In: Mendo Ze, Gervais (éd.): Le français langue africaine: Enjeux et atouts pour la Francophonie. Paris: 80-95.

Bitja'a Kody, Zachée Denis (2001): "Emergence et survie des langues nationales au Cameroun". TRANS No. 11/2001. Internet-Zeitschrift für Kulturwissenschaften. http://www.inst.at/trans/11Nr/kody11.htm.

Bokamba, Eyamba G. (1991): "French Colonial Language Policies in Africa and their Legacies". In: Marshall, David F. (ed.): Language Planning: Focusschrift in Honor of Joshua A. Fishman, Vol. III. Amsterdam/Philadelphia: 175-213.

Bot Ba Njok, Henri Marcel (1966): "Le problème linguistique au Cameroun". L'Afrique et l'Asie No. 73: 3-13.

Boum Ndongo-Semengue, M.A./Sadembouo, Etienne (1999): "L'Atlas linguistique du Cameroun: les langues nationales et leur gestion". In: Mendo Ze, Gervais (ed.): Le français langue africaine: Enjeux et atouts pour la Francophonie. Paris: 67-79.

Breton, Roland/Fohtung, Bikia (1991): Atlas administratif des langues nationales du Cameroun. Yaoundé, Paris: CERDOTOLA, CREA - ACCT.

Chumbow, Sammy Beban (1996): "The Role of National Languages within a Comprehensive Language Policy for Cameroon". Academic Discourse presented at the University of Buea.

Fonlon, Bernard (1963): "A Case for Early Bilingualism". ABBIA No. 4: 56-94.

Mba, Gabriel/Chiatoh Blasius (2000): "Current trends and Perspectives in Mother Tongue Education in Cameroon". African Journal in Applied Linguistics (AJAL) No. 1: 1-21.

Mbuagbaw, Tanyi Eyong (2000): "Language and Education in Cameroon: A Sociolinguistic Perspective". African Journal of Applied Linguistics (AJAL) No.1: 135-145.

Mendo Ze, Gervais (ed.) (1999): Le français langue africaine: Enjeux et atouts pour la Francophonie. Paris.

Nga Minkala, Alice (1993): Les langues nationales à la CRTV. Doctorate thesis, Université de Paris II, Sorbonne.

Ngijol, Pierre (1964): "Nécessité d'une langue nationale". ABBIA No. 7: 83-99. 
Njeck, Alice Forsab (1992): Official Bilingualism in the University of Yaounde: Some Educational and Social Issues. Mémoire de Maîtrise, Université de Yaoundé.

Stumpf, Rudolf (1979): La politique linguistique au Cameroun de 1884 à 1960. Berne.

Tadadjeu, Maurice (1975): "Language Planning in Cameroon: Towards a Trilingual Education System". In: Herbert, Robert K. (ed.): Patterns in Language, Culture and Society: Sub-Saharan Africa. Colombus, Ohio: 53-75. (= Working Papers in Linguistics 19).

Tambi, Jot (1973): Received Language Bilingualism in Cameroon: A Study of Functions and Attitudes. Mémoire du DES, Université de Yaoundé.

Todd, Loreto (1983): "Language Options for Education in a Multilingual Society: Cameroon". In: Kennedy, Chris (ed): Language Planning and Language Education. London: 160-171.

Wolf, Hans-Georg (1997): "Transcendence of Ethnic Boundaries: The Case of the Anglophones in Cameroon". Journal of Sociolinguistics 1(3): 419-426.

Wolf, Hans-Georg (2001): English in Cameroon. Berlin/New York. 